\title{
The effectiveness of the internal corporate governance mechanism and the ownership of the gov- ernment and agencies
}

\author{
Khaled Salmen Aljaaidi ${ }^{a^{*}}$
}

${ }^{a}$ Accounting Department, College of Business Administration, Prince Sattam bin Abdulaziz University, Saudi Arabia

\begin{tabular}{l}
\hline C H R O N I C L E \\
\hline Article history: \\
Received: February 27, 2021 \\
Received in revised format: \\
April 292021 \\
Accepted: May 6, 2021 \\
Available online: \\
May 6, 2021 \\
\hline Keywords: \\
Government ownership \\
Board of directors' effectiveness \\
Saudi Arabia
\end{tabular}

\section{Introduction}

Ownership structures are an essential element of governance, particularly when a well-designed legal framework is not present. Ownership structures are becoming increasingly popular, with numerous organizations finding them a viable alternative (Eng \& Mak, 2003; Barako et al., 2006; Ntim \& Soobaroyen, 2013). Dominant internal shareholders frequently exploit the advantages of private control, which gives them insider access to crucial data (Shleifer \& Vishny, 1986; Dyck \& Zingales, 2004). Internal shareholders have the capacity of controlling and influencing directors to defend their own interest over those of other parties (Coffee, 1991; Shleifer \& Vishny, 1986). Dominant controlling shareholders are not incentivized to promote board control or audit committees, since the more intensely the environment is monitored, the more expensive it will be for them to leverage the situation for private gain (Leftwich et al., 1981; Shleifer \& Vishny, 1997). Owing to this, these shareholders become a controlling force in the company and employ their influence over directors for the advancement of their own interest (Mendez \& Garcia, 2007). Greco (2010) suggests that ownership in the hand of insiders has a negative influence on the frequency of board and/or audit committee meetings. Specifically, ownership structures are generally regarded as being a central influence on the ways directors behave. The ownership structure of the companies headquartered in the Gulf Corporation Council (GCC) area has been alleged to be a primary source of corporate governance difficulties in the region. Niemi (2005) proposes that there should be a holistic debate regarding ownership, suggesting that a focus on concentration ownership with no examination of alternatives could cause erroneous assumptions to be made about the part various owners play.

\footnotetext{
* Corresponding author.

E-mail address: k.aljaaidi@psau.edu.sa (K. S. Aljaaidi)
}

(C) 2021 by the authors; licensee Growing Science, Canada doi: $10.5267 /$ j.ac. 2021.5 .005 
In Saudi Arabia, concentrated ownership of companies is quite common as the majority of listed companies are owned by the government (Al-Janadi, Rahman \& Alazzani, 2016). Baydoun and Willett (2006) state that firms based in the GCC are generally owned by the government. The government of Saudi Arabia owns a huge majority of the shares in the publicly listed firms in the country. This massive government share in public companies is attributable to the fact that the government tends to privatize companies. Additionally, the Treasury of the Saudi Arabian government frequently invests in listed companies, increasing government shareholdings in such companies further. (Al-Janadi et al., 2016; Baydoun and Willett, 2006). The majority of companies in government ownership and control are generally sensitive politically because their operations are subject to public scrutiny. It is highly expected that these organizations should be conscientious in their operations (Ghazali, 2007). Some research findings report negative issues regarding government-owned companies in terms of performance (Megginson and Netter, 2001; Shleifer, 1998), poor reporting of conservative earnings (Bushman \& Piotroski, 2006), a lack of proper transparency (Bushman et al., 2004), pay back the voters for their support, for contributing politically, and for their bribery (Rajan \& Zingales, 2003; Shleifer \& Vishny, 1993, 1994; La Porta et al., 2002), voluntary disclosure (Al-Janadi et al., 2016), the focus on implementing governmental objectives at the expense of shareholders' objectives (Firth \& Rui, 2007), disclose earnings with lower quality in their report (Chaney, Faccio \& Parsley, 2011), acquire the property of minority investors for public use (La Porta et al., 2002; Shleifer \& Vishny, 1997) and offer financial insurance to outside shareholders in exchange for political and financial support (Wang et al., 2008), and less modified opinions reported (Chen et al., 2000).

Government control over a board of directors is regarded as a strategy employed by the state for protection of its own interests and property values. The majority of the board members that represent the government receive recompense from local government dependent on their administrative rank rather than the quality of their performance (Xu \& Wang, 1999; Zhou \& Wang, 2000). They may not have sufficient management skills to be effective supervisors of a variety of management behaviors. In addition, the priorities of local government are not necessarily the same as that of the national government. It should be noted that government influence on the board of directors frequently involves interference in management structures. The government may at times demand a move away from the pursuit of maximum profit, focusing instead on developing infrastructure and maximizing social benefits. Empirically, some prior studies investigated individually the characteristics of board meeting in different settings (Sharma, Bagais and Aljaaidi, 2021; Aljaaidi, Bagai \& AlAbdullatif, 2021; Greco, 2010; Vafeas, 1999; Hahn \& Lasfer, 2007; Baccouche and Omri, 2014; Hahn \& Lasfer, 2016; Lin et al., 2014). Regarding the characteristics of board of directors and the ownership, Greco (2010) looked at the correlations between insider ownership/ownership concentrations and board meeting frequency. This research revealed a negative correlation between insider ownership and board meeting frequency. Al-Janadi, Rahman \& Alazzani (2016) looked at the moderating influence of the ownership of corporations linked with government and the correlation of voluntary disclosure and corporate governance. The research showed that the ownership of corporations linked with the government has a negative influence in the moderation of the correlation between corporate government elements, i.e., voluntary disclosure, board size, and non-executive directors. This indicates that corporations linked to the government are negatively impacted in terms of effective corporate governance. It's important to note that existing research regarding board of directors' discipline does not take into account the degree to which government ownership of a corporation limits the power of its board of directors. This research represents an attempt to make good this lack in previous research. Additionally, this research measures a company board of directors' power employing composite measures of frequency of board meetings and size of board. The outcomes demonstrate that measuring the overall impact of a combination of factors shows stronger influences than measuring individual influences (Cai et al., 2009; Ward et al., 2009; Agrawal \& Knoeber, 1996; O’Sullivan et al., 2008). To the best of our awareness, a study examining the impact of the government-linked corporations on the effectiveness of the board of directors does not exist, giving a contribution to the extant literature.

The paper proceeds as follows: Section 2 describes the research design and methodology. Section 3 highlights the empirical results and discussions. Section 4 provides the conclusions and implications.

\section{Research Design and Methodology}

\subsection{Sample and Data}

This study utilized a number of 140 firm-year observations for energy and petrochemical companies listed in Saudi Stock Exchange that their corporate governance and financial information are publicly available for the period 2012-2019. The data was collected by hand from the financial statements. The final sample is depicted in the following Table 1:

Table 1

Sample size

\begin{tabular}{lc}
\hline & Totals \\
\hline Total listed companies & 18 firms \\
Number of years observed & 8 years \\
Total observation & 144 \\
Missed data & $(4)$ \\
\hline Final sample & 140 \\
\hline
\end{tabular}




\subsection{Model Specification}

Testing the board of directors' effectiveness model, the Pooled Ordinary least square model $O L S$ was utilized to show the degree of influence of government-linked corporations' ownership GLCO, and the control variables, namely; family ownership FOWN, domestic corporate ownership DOMOWN, firm size FSIZE, firm leverage $L E V$ and firm performance ROA on the effectiveness of board of directors.

$\begin{array}{lll}B D E F F=\beta_{0}+\beta_{1} G L C O+\beta_{2} F O W N & +\beta_{3} & D O M O W N+\beta_{4} F S I Z E+\beta_{5} L E V+\beta_{6} R O A+e \\ B D E F F & = & \text { Interaction term of board size and board meetings } \\ \text { GLCO } & = & \text { Percentage of ordinary shares held by the government and its agencies } \\ F O W N & = & \text { Percentage of ordinary shares held by a family } \\ \text { DOMOWN } & = & \text { Percentage of ordinary shares held by domestic companies } \\ \text { FSIZE } & = & \log _{10} \text { of total assets } \\ \text { LEV } & = & \text { Debt to total assets ratio } \\ \text { ROA } & = & \text { Return on assets } \\ e & = & \text { error term. }\end{array}$

This study controls for several variables. Family ownership FOWN was negatively associated with board effectiveness (Aljaaidi \& Bagais, 2021). Domestic corporate ownership was positively related to audit committee diligence (Aljaaidi, 2021). Firm size FSIZE is expected to have a positive relationship with board of directors' effectiveness BDEFF (Aljaaidi \& Bagais, 2021; Greco, 2010; Hahn, 2007; Brick \& Chidambaran, 2010; Lin, Yeh, \& Yang, 2014; Baccouche \& Omri, 2014). Firm leverage $L E V$ is expected to have a positive association with the board of directors' effectiveness $B D E F F$ (Greco, 2010; Baccouche \& Omri, 2014; Hahn \& Lasfer, 2016). As for the firm performance $R O A$, the sign is expected to be negative in relationship with board of directors' effectiveness BDEFF (Aljaaidi, 2021; Aljaaidi, Alothman, Sharam \& Bagais, 2021; Vafeas, 1999; Brick \& Chidambaran, 2010; Hahn \& Lasfer, 2007; Baccouche \& Omri, 2014; Hahn \& Lasfer, 2016; Al-Najjar, 2012; Adams \& Ferreira, 2007).

\section{Empirical Results and Discussions}

The descriptive statistics are illustrated in 2. These include the mean, standard deviation, minimum and maximum of each variable in the sample data set.

Table 2

Descriptive statistics

\begin{tabular}{lcccc}
\hline BDEFF & Minimum & Maximum & Mean & Std.Deviation \\
\hline BDSIZE & 14 & 90 & 42.5 & 12.77067 \\
BDMEET & 6 & 11 & 9 & 1.15096 \\
GLCO & 2 & 10 & 5 & 1.44760 \\
FOWN & 0 & 0.79 & .14 & .209 \\
DOMOWN & .00 & .70 & .0441 & .10757 \\
FSIZE & 0 & 0.88 & .19 & .201 \\
LEV & 155992568.00 & 340041000000.00 & 30948759882.1000 & 74823531813.29596 \\
ROA & .01 & .86 & .4007 & .23474 \\
\hline
\end{tabular}

Table 2 shows that differences in values exist among the variables included in the model of this study. It is shown that the range of $B D E F F$ is from 14 to 90 with an average of 42.5 and a standard deviation of 12.77067 . The mean of $B D S I Z E$ is 9 with a maximum of 11 and a minimum of 6 and a standard deviation of 1.15096 . The mean of BDMEET is 5 with a maximum of 10 and a minimum of 2 and a standard deviation of 1.44760 . The range of GLCO is from .00 to 0.79 with an average of .14 and a standard deviation of .209. The range of FOWN is from .00 to 0.70 with an average of .0441 and a standard deviation of .10757. The range of DOMOWN is from .00 to 0.88 with an average of .19 and a standard deviation of .201. The range of FSIZE is from 155992568 to 340041000000 with an average of 30948759882.10 and a standard deviation of 74823531813.29596. The range of $L E V$ is from .01 to .86 with an average of .4007 and a standard deviation of .23474. The mean of $R O A$ is .2068 with a maximum of .90 and a minimum of -.05 and a standard deviation of .29435 .

Pooled Ordinary-Least Square $(O L S)$ was utilized to test the level of effect of government-linked corporations' ownership with the power of the board of directors' effectiveness. Table 3 reports that the adjusted $R^{2}$ is 0.37 , indicating that the model has explained $37 \%$ of the variance in the board of directors' effectiveness. The $F$-value for the model is statistically significant at the $1 \%$ level, indicating that the overall model can be interpreted. This also gives an indication that the board of directors' model is a good fit. 
Table 3 displays that $G L C O$ has a negative relationship with the board of directors' effectiveness $B D E F F(t=-3.611, p$-value $<.001$, one-tailed significance). This result gives support to the previous empirical studies such as (Megginson and Netter, 2001; Bushman \& Piotroski, 2006; Bushman et al., 2004; Rajan \& Zingales, 2003; La Porta et al., 2002; Al-Janadi et al., 2016; Firth \& Rui. 2007; Chaney, Faccio \& Parsley, 2011; La Porta et al., 2002; Wang et al., 2008; Chen et al., 2000). The results of this study also indicated that family ownership FOWN is negatively associated with board of directors' effectiveness $B D E F F(\mathrm{t}=-2.455, p$-value $<0.020$, one-tailed significance). This result is consistent with Brunninge and Nordqvist (2004). The results of this study showed that there is a positive relationship between domestic corporate ownership DOMOWN and board of directors' effectiveness $B D E F F(t=2.761$, $p$-value $<0.010$, one-tailed significance). This result is in line with several previous studies (Chibber \& Majumdar, 1999; Djankov \& Hoekman, 2000; Khanna \& Palepu, 2000; Barbosa and Louri, 2005; Claessens et al., 2000; Dharwadkar, George \& Brandes, 2000; Douma et al., 2006). The results of this study also depicted that firm size FSIZE is marginally and positively associated with board of directors' effectiveness $B D E F F(\mathrm{t}=1.509, p$-value $<$ 0.142, one-tailed significance). This result is consistent with Aljaaidi and Bagais (2021), Greco (2010), Hahn (2007), Brick \& Chidambaran (2010), Lin, Yeh, and Yang (2014), Baccouche and Omri (2014). The results of this study also illustrated that leverage $L E V$ has a positive association with the board of directors' effectiveness $B D E F F(\mathrm{t}=1.938, p$-value $<0.062$, onetailed significance). This result is consistent with the extant research (Greco, 2010; Baccouche and Omri, 2014; Hahn and Lasfer, 2016). The results of this study reported a positive association of firm performance ROA with board of directors' effectiveness $B D E F F(\mathrm{t}=1.846, p$-value $<0.075$, one-tailed significance). This results in inconsistent with the previous studies' results (Aljaaidi, 2021; Aljaaidi, Alothman, Sharam and Bagais, 2021; Vafeas, 1999; Brick and Chidambaran, 2010; Hahn, 2007; Baccouche and Omri, 2014; Hahn and Lasfer, 2016; Al-Najjar, 2012; Adams \& Ferreira, 2007).

Table 3

Pooled OLS Analysis Results (Board effectiveness model)

\begin{tabular}{|c|c|c|c|c|c|}
\hline Variables & 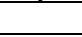 & Expected Sign & Coef. & $t$ & $P>|\mathbf{t}|$ \\
\hline \multicolumn{6}{|c|}{ Test variable } \\
\hline GLCO & & - & -211.215 & -3.611 & .001 \\
\hline \multicolumn{6}{|c|}{ Control variables } \\
\hline DOMOWN & & & 79.453 & 2.761 & .010 \\
\hline FSIZE & & & 8.370 & 1.509 & .142 \\
\hline LEV & & & 32.272 & 1.938 & .062 \\
\hline $\mathrm{ROA}$ & & & 17.418 & 1.846 & .075 \\
\hline$F$ & 4.471 & & & & \\
\hline Adjusted $R^{2}$ & 0.37 & & & & \\
\hline$P$-value & 0.002 & & & & \\
\hline
\end{tabular}

\section{Additional Analysis}

Additional analysis has been carried out to examine the extent to which our results are sensitive to the individual variables consisting the board of directors' effectiveness which are board size BDSIZE and board meetings BDMEET.

Table 4

Pooled OLS Analysis Results (Board meeting model)

\begin{tabular}{|c|c|c|c|c|c|}
\hline Variables & & Expected Sign & Coef. & $t$ & $P>|t|$ \\
\hline \multicolumn{6}{|c|}{ Hypothesized Variable } \\
\hline GLCO & & - & -24.344 & -3.327 & .002 \\
\hline \multicolumn{6}{|c|}{ Control Variables } \\
\hline FOWN & & & -51.792 & -3.236 & .003 \\
\hline DOMOWN & & & 12.250 & 3.403 & .002 \\
\hline FSIZE & & & .116 & .167 & .868 \\
\hline LEV & & & 3.955 & 1.899 & .067 \\
\hline ROA & & & 3.812 & 3.229 & .003 \\
\hline$F$ & 2.684 & & & & \\
\hline Adjusted $R^{2}$ & 0.219 & & & & \\
\hline$P$-value & 0.033 & & & & \\
\hline
\end{tabular}

Table 4 shows that the results of the board meeting model are identical with those of the original model of the board of directors' effectiveness. This gives evidence that the results of the board meeting as an individual dependent variable are not sensitive to the results produced when using the board meeting as one of the individual variables consisting the score of board of directors' effectiveness. Table 5 depicts that the results of the board size model are different to some extent with those of the original model of the board of directors' effectiveness. This gives evidence that the results of the board size as an individual dependent variable are sensitive to some extent compared with those produced when using the board size as one of the individual variables consisting the score of board of directors' effectiveness. The difference in the results were reported for the government ownership as its relationship was negative and significant in the original model, board of directors' effectiveness. While in the board size model the result was insignificant ( $t=-1.181, p$-value $<0.247$, one-tailed significance). 
Table 5

Pooled OLS Analysis Results (Board size model)

\begin{tabular}{|c|c|c|c|c|c|}
\hline Variables & & Expected Sign & Coef. & $t$ & $P>|\mathbf{t}|$ \\
\hline \multicolumn{6}{|c|}{ Hypothesized Variable } \\
\hline GLCO & & - & -3.540 & -1.181 & .247 \\
\hline \multicolumn{6}{|c|}{ Control Variables } \\
\hline FOWN & & - & 19.119 & 2.916 & .007 \\
\hline DOMOWN & & + & -3.938 & -2.669 & .012 \\
\hline FSIZE & & & 1.282 & 4.509 & .000 \\
\hline LEV & & & .698 & .818 & .420 \\
\hline ROA & & & -2.533 & -5.236 & .000 \\
\hline$F$ & 60.058 & & & & \\
\hline Adjusted $R^{2}$ & 0.908 & & & & \\
\hline$P$-value & 0.000 & & & & \\
\hline
\end{tabular}

Bold $=$ significance at $1 \%, 5 \%$ and $10 \%$ (one-tailed significance)

\section{Conclusions and Implications}

Using a sample of 140 firm-year observations from energy and petrochemical industries, this study has examined the impact of the government-linked corporations' ownership on the power of their board of directors in Saudi Arabia. The setting of Saudi Arabia provides an interesting institutional setting for this issue due to the domination of the government and its agencies on companies. Therefore, the negative impact of the government-linked local corporations is likely to reflect the malfunction of their board of directors' advisory and monitoring roles. This might give an indication that the government focuses on the economic, social and other purposes rather than the profitability purpose. Our key conclusion is that the ownership of the government-linked local corporations impacts negatively on its board of directors. This result is sensitive to the measurement of the board of directors used in the study which is the interaction term of the board size and meetings. As the result indicated a negative association between the ownership of the government-linked local corporations and board of directors' meetings and this association has not been found for the board size. Our results are consistent with the agency theory prediction and the substitution hypothesis. The results reported by this study are somewhat inconclusive on the measurement of the board of directors' effectiveness. This study used an interaction term of the most common board of directors' characteristics, board size and meetings, as the measurement for the board of directors' effectiveness. Future line of research may use a composite measurement for the board of directors' effectiveness of several board of directors' characteristics such as financial expertise, CEO duality, and multiple directorships. In specific, this study contributes to the extant research by providing an empirical evidence of the association between the government-linked local corporations and the effectiveness of their board of directors in the context of Saudi Arabia. Future studies may extend this model to the other GCC countries to examine its validity. The findings of this study have theoretical contribution to the agency theory and practical implications for Saudi market, companies' management, and external auditors.

\section{References}

Adams, R. B., \& Ferreira, D. (2007). A theory of friendly boards. The Journal of Finance, 62(1), 217-250.

Agrawal, A., \& Knoeber, C. R. (2001). Do some outside directors play a political role?. The Journal of Law and Economics, 44(1), 179-198.

Aljaaidi, K. (2021). Ownership of local corporations and audit committee diligence: An empirical evidence from an emerging economy. Accounting, 7(5), 1095-1100.

Aljaaidi, K. S., \& Hassan, W. K. (2020). Energy Industry Performance in Saudi Arabia: Empirical Evidence. International Journal of Energy Economics and Policy, 10(4), 271-277.

Aljaaidi, K. S., Bagais, O. A., \& Adow, A. H. E. (2021). The Impact of Board Activity on The Audit Committee's Effectiveness Score: Empirical Evidence from Saudi Arabia. The Journal of Asian Finance, Economics, and Business, 8(1), 179-185.

Aljaaidi, K., \& Bagais, O. (2021). Major shareholders and the effectiveness of the management's advising and monitoring functions: Empirical study. Accounting, 7(6), 1251-1256.

Aljaaidi, K., \& Bagais, O. (2021). The effect of company performance on audit committee diligence: The case of manufacturing companies in Saudi Arabia. Accounting, 7(2), 391-394.

Aljaaidi, K., Alothman, A., Sharma, R., \& Bagais, O. (2021). The controlling power of royal family members on the board of directors and audit committee effectiveness. Accounting, 7(5), 987-992.

Aljaaidi, K., Bagais, O., \& AlAbdullatif, S. (2021). Audit efficiency and board activity in Saudi Arabia: Empirical investigation. Accounting, 7(4), 893-898.

Aljaaidi, K., Sharma, B., \& Bagais, O. (2021). The effect of board characteristics on the audit committee meeting frequency. Accounting, 7(4).

Al-Janadi, Y., Rahman, R. A., \& Alazzani, A. (2016). Does government ownership affect corporate governance and corporate disclosure?. Managerial Auditing Journal, 31(8/9), 871-890

Al-Najjar, B. (2012) The determinants of board meetings: evidence from categorical analysis. Journal of Applied Accounting Research, 13, 178-90.

Baccouche, S., Hadriche, M., \& Omri, A. (2014). Multiple directorships and board meeting frequency: Evidence from France. Applied Financial Economics, 24(14), 983-992. 
Bagais, O., \& Aljaaidi, K. (2020). Corporate governance attributes and firm performance in Saudi Arabia. Accounting, 6(6), 923930.

Barako, D.G., Hancock, P., \& Izan, H. (2006). Factors influencing voluntary corporate disclosure by Kenyan companies. Corporate Governance: An International Review, 14(2), 107-125.

Baydoun, N., \& Willett, R. (2006). The Impact of Islam on the Harmonisation of Accounting Practices Among the Gulf Cooperation Countries. Islam and Accounting: Towards Enhancing Accountability, Governance and Performance, 26-28.

Brick, I. E., \& Chidambaran, N. K. (2010). Board meetings, committee structure, and firm value. Journal of Corporate finance, 16(4), 533-553.

Bushman, R. M., Piotroski, J. D., \& Smith, A. J. (2004). What determines corporate transparency?. Journal of Accounting Research, 42(2), 207-252.

Cai, J., Liu, Y., \& Qian, Y. (2009). Information asymmetry and corporate governance. Drexel College of Business Research Paper No. 2008-02.

Chaney, P. K., Jeter, D. C., \& Shivakumar, L. (2004). Self-selection of auditors and audit pricing in private firms. The Accounting Review, 79(1), 51-72.

Chen, C. J., \& Jaggi, B. (2000). Association between independent non-executive directors, family control and financial disclosures in Hong Kong. Journal of Accounting and Public Policy, 19(4-5), 285-310.

Coffee, J. C. (1991). Liquidity versus control: The institutional investor as corporate monitor. Columbia Law Review, 91(6), 12771368.Dyck, A., \& Zingales, L. (2004). Private benefits of control: An international comparison. The Journal of Finance, 59(2), 537-600.

Eng, L. L., \& Mak, Y. T. (2003). Corporate governance and voluntary disclosure. Journal of Accounting and Public Policy, 22(4), 325-345.

Firth, M., \& Rui, O. M. (2007). Voluntary audit committee formation and agency costs. International Journal of Accounting, Auditing and Performance Evaluation, 4(2), 142-160.

Ghazali, N.A.M. (2007). Ownership structure and corporate social responsibility disclosure: some Malaysian evidence. Corporate Governance, 7(3), 251-266.

Greco, G. (2011). Determinants of board and audit committee meeting frequency. Managerial Auditing Journal, 26(3), 208-229

Hahn, P. D., \& Lasfer, M. (2007). Vanishing board meetings: Has governance doomed the board meeting. London: Cass Business School Research Paper.

Hahn, P. D., \& Lasfer, M. (2016). Impact of foreign directors on board meeting frequency. International Review of Financial Analysis, 46, 295-308.

Hassan, W. K., Aljaaidi, K. S., Bin Abidin, S., \& Nasser, A. M. (2018). Internal corporate governance mechanisms and audit quality: Evidence from GCC region. International Journal of Advanced and Applied Sciences, 5(8), 72-90.

La Porta, R., Lopez - de - Silanes, F., Shleifer, A., \& Vishny, R. (2002). Investor protection and corporate valuation. The Journal of Finance, 57(3), 1147-1170.

Leftwich, R. W., Watts, R. L., \& Zimmerman, J. L. (1981). Voluntary corporate disclosure: The case of interim reporting. Journal of Accounting Research, 19, 50-77.

Lin, Y. F., Yeh, Y. M. C., \& Yang, F. M. (2014). Supervisory quality of board and firm performance: a perspective of board meeting attendance. Total Quality Management \& Business Excellence, 25(3-4), 264-279.

Megginson, W. L., \& Netter, J. M. (2001). From state to market: A survey of empirical studies on privatization. Journal of Economic Literature, 39(2), 321-389.

Méndez, C. F., \& García, R. A. (2007). The effects of ownership structure and board composition on the audit committee meeting frequency: Spanish evidence. Corporate Governance: An International Review, 15(5), 909-922.

Ntim, C. G., \& Soobaroyen, T. (2013). Corporate governance and performance in socially responsible corporations: New empirical insights from a Neo - Institutional framework. Corporate Governance: An International Review, 21(5), 468-494.

O’Sullivan, M., Percy, M., \& Stewart, J. (2008). Australian evidence on corporate governance attributes and their association with forward-looking information in the annual report. Journal of Management and Governance, 12(1), 5-35.

Rajan, R. G., \& Zingales, L. (2003). The great reversals: the politics of financial development in the twentieth century. Journal of Financial Economics, 69(1), 5-50.

SHARMA, R. B., BAGAIS, O. A., \& ALJAAIDI, K. S. (2021). Government-Controlled Companies and Audit Committee Effectiveness: An Empirical Study on Saudi Stock Exchange. The Journal of Asian Finance, Economics and Business, 8(4), 363368.

Shleifer, A. (1998). State versus private ownership. Journal of Economic Perspectives, 12(4), 133-150.

Shleifer, A., \& Vishny, R. W. (1986). Large shareholders and corporate control. Journal of Political Economy, 94(3, Part 1), 461488.

Ward, A. J., Brown, J. A., \& Rodriguez, D. (2009). Governance bundles, firm performance, and the substitutability and complementarity of governance mechanisms. Corporate Governance: An International Review, 17(5), 646-660.

Xu, X., \& Wang, Y. (1999). Ownership structure and corporate governance in Chinese stock companies. China Economic Review, 10(1), 75-98.

Zhou, M., \& Wang, X. (2000). Agency cost and the crisis of China's SOE. China Economic Review, 11(3), 297-317.

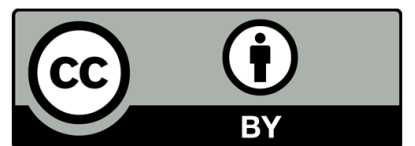

(C) 2021 by the authors; licensee Growing Science, Canada. This is an open access article distributed under the terms and conditions of the Creative Commons Attribution (CC-BY) license (http://creativecommons.org/licenses/by/4.0/). 